\title{
Food security challenges in Nigeria: a paradox of rising domestic food production and food import
}

\author{
G. T. Ahungwa, U. Haruna, B. G. Muktar \\ Department of Agricultural Economics and Extension, Federal University Dutse, \\ P.M.B. 7156, Dutse, Nigeria
}

\begin{abstract}
This paper examined the food security challenges vis-á-vis the paradox of increased domestic food production and food import in Nigeria. The study used time-series data from National Bureau of Statistic, Central Bank of Nigeria, Nigeria's National Dailies and CIA Factbook reports. The trend analysis showed that the share of agriculture to the total Gross Domestic Product, GDP had a downward trend, especially from 1960-1979, where food import hovered around $2.92 \%$ from 196074 and up to $9.85 \%$ in 1975-79 of GDP. The result depicts an undulating trend in the contribution of agriculture and food import values to 2009 where food import rose astronomically from $\$ 2.6$ trillion (3.83\%) in 2005-2009 to about $\$ 20.6$ trillion (25.02\%) in 2010-2012. Results of the regression analysis confirmed that agriculture has a positive relationship with GDP, and contributes significantly with a coefficient of 0.852 . The paradox however is that food import negates the a priori expectation as it is found to be positively related to the GDP: as food production increases marginally, food importation increases asymptotically. The paper recommends that reliance on food import could be minimized through increased budgetary allocation to the sector, and improvement in postharvest management practices that have hitherto, aggravated food insecurity in the country.
\end{abstract}

Keywords: Food security; Paradox; Domestic food production; Food import; Nigeria

\section{INTRODUCTION}

The United Nations Food and Agriculture Organization (FAO) has warned repeatedly of catastrophic food shortages in Africa, because the average per capita calorie intake in majority of African countries has now fallen below the minimum nutritional standards, considering the relatively poor performance of the agricultural sector. The warning outlined one of the important challenges for agriculture in development as the neglect of this sector in the development priorities of the governments of African countries (Ehigiamusoe, 2012). This development has predisposed the continent to the twin jeopardy of severe poverty and a glaring state of food insecurity.

Recent statistics depicts that, the agricultural sector in Nigeria has not been able to fulfill its traditional roles of feeding the population, meeting the raw materials needs of industries, as well as providing substantial export earnings for the economy. Indeed, the 
contribution of the sector to total Gross Domestic Product (GDP) has been falling, not necessarily because a strong industrial sector is displacing agriculture but as a result of low productivity. The largely subsistence agricultural sector has failed to keep up with rapid population growth of Africa's most populous country - a once a large net exporter of food, but now a net food importer (Nwajiuba, 2012).

It is on record that Nigeria faces huge food security challenges as about 70 percent of the population lives on less than US\$ 1.25 per day, thus, suffering from hunger and poverty (Nwajiuba, 2012). Nigeria's claim to remain an agrarian economy hinges on two key facts. The first is the share of agriculture in the Gross Domestic Product (GDP) and the second is the proportion of the population engaged in the agricultural sector. On both scores, the agricultural sector contributes more than any other sector of the economy, providing over 40 $\%$ of GDP while the population of Nigeria involved in farming is between 60 and $70 \%$ (Nwajiuba, 2012). However, according to the Nigeria's senate President, David Mark as quoted in Thisday Newspaper (May, 3, 2012), Nigeria still spends about N24.5 trillion on food importation per annum.

Nigeria is naturally blessed with abundant land and water resources, which have given the nation's agricultural sector high potentials for increased growth, but these potentials are not being fully realized, prompting the nation to set up the Vision 2020 wherein, agriculture is pivotal to its realization of positioning herself amongst the $20^{\text {th }}$ world leading economies by the year 2020. Despite all these obvious abundant human and natural resources, the country is still unable to feed its' citizens, producing for instance, about 500,000 tons of rice while the annual consumption is 2.5 million tons, according Nigeria the world's secondlargest rice importer after Singapore. Over the past 20 years, food production increase has not kept pace with population growth, resulting in rising food imports and declining levels of national food self-sufficiency (FGN, 2009).

No country can truly be a sovereign nation if it is not capable of ensuring food security for its citizens. Histories have shown that no nation has actually become great without developing its agriculture and its concomitant institutions (Isife and Abert, 2009). Experts have argued that significant food and nutrition problems exist in Nigeria (Olayide, 1982; Famoriyo, 1998; Okuneye 2002; Ahungwa et al, 2013). Recent estimates put the number of hungry people in Nigeria at over 53 million of the country's total population and that 52 per cent of the populace lives below the poverty line (Azubike, 2012).

Statistics have shown that Nigeria has become a floodgate for food imports. For a country that has the potentials of supporting a wide range of agricultural ventures, still spends over $\$ 635$ billion on import of wheat, $\$ 356$ billion on import of rice, $\$ 217$ billion on sugar importation and despite the huge marine resources spent N97 billion importing fish as of 2010 (Adesina as quoted by Azubike, 2012). At the moment, Nigeria's food import has risen from $\$ 3$ billion in 2009, \$11 billion in 2010/11 to N24.5 trillion in 2012 as affirmed by Corporate Nigeria, (2009), Osagie (2013) and the Nigeria's senate president, David Mark (2012). The loss of food sovereignty and the dependence on food importation are also making the country quite susceptible to fluctuations in global food crisis. This explained why Nigeria was strongly affected by the global food crisis in 2007/2008.

The immediate response to the recent food crisis in the country propelled the Federal Government, through the ministry of agriculture and water resources then, to facilitate the development of a National Food Crisis Response Programme (NFCRP), The Food Security Thematic Group (FSTG), established in 2009 and the Food and Agricultural Organization (FAO) was invited to provide guidance. The Agricultural Transformation Agenda and Growth Enhancement Support Scheme were also introduced with the primary objective of 
import substitution to deal with the hidden hunger crisis confronting the country (Osagie, 2013).

Despite demonstrated efforts at building institutions to address hunger and poverty in the country, no further step has since been taken to consolidate set agenda. It is in this light that the paper seeks to examine the paradox of the Nigeria's massive food import amidst plenty opportunities of domestic food production.

\section{CONCEPTUAL AND EMPIRICAL ISSUES}

Agricultural production was the mainstay of Nigeria's economy and a source of food. In the colonial era and briefly after independence, agriculture played a dominant role in the nation's economy from the standpoint of adequate food for its population. According to Akande (1998) at independence agriculture was able to match the expectation ascribed to it as regards food security.

Today, domestic food production is on the rise in Nigeria but it is not enough to meet the national food demand, worst still losses of produced crops are on the rise because processing and storage of crops are not adequately done (FGN, 2009). Nutritious foods are limited by low income, and poverty stricken citizens; most nutritious food is often expensive, food intake and nutritional wellbeing of many households is of relatively low quantity, and is affected by their low economic status. According to FAO (2011) households' food insecurity, under nutrition and micro nutrient deficiencies are found throughout Nigeria.

Ogen (2003) posits that during the first ten years after independence Nigeria could be seen as an agricultural economy because agriculture was the engine of growth of its overall economy, during this time Nigeria was the world's second largest producer of cocoa, and highest producer and exporter of palm-kernel and palm-oil. According to Lawal (1997) then Nigerian farmers produced $70 \%$ of Nigerian export and $95 \%$ of its food needs, thus helping to contribute immensely to the maintenance of a healthy population; and a source of food and nutrition for households in Nigeria. However, it has not done well enough, especially from the time the country started the production of crude oil in commercial quantity in the mid 1960's till now.

It was observed that, the volume of commodity output is inconsistent, even when it increases marginally and this showed poor performances of agricultural sector. However, a lot was said on the reasons of these poor performances, for example Abdulrahaman (2013) and Iganiga and Unemhilin (2011) attributed the problem to low budgetary allocation to the sector. In his opinion, Aditoloye (2012) blamed insufficient funds and how these funds are disbursed to the farmers by Agricultural Credit Guarantee Scheme. On the contrary, Iwuchukwu and Igbokwe (2012) put the blames on poor policies and agricultural programs.

\section{FOOD SECURITY IN NIGERIA}

The food security in Nigeria hangs on a very delicate balance of domestic food production and volatile food imports, as asserted by many experts. Although the number of people faced with the problem of acute starvation in the country may not be alarming at the moment, like it is in some parts of the world, especially in the horn of Africa, a jolt on Nigeria's food supply system could push the country into a hunger challenge of adverse proportion. 
Analysts have always noted that Nigeria's current food security is by no means sustainable. The most populous black nation on earth became a net importer of food, squandering \$11 billion importing basic food commodities including wheat on which N635 billion was expended yearly and rice, on which Nigeria spent N356 billion annually, amounting to about N1 billion per day. So, although Nigeria is not currently enmeshed in famine, extreme lack of food or starvation, it is mainly for one reason only, and that is because every day, it still sells enough crude oil to purchase sufficient food to salvage its population from the brink of starvation. But this clearly is not a sustainable way to feed about 170 million people (Osagie, 2013).

A lot has been written on food crisis in Nigeria, a country once considered as a major food exporter now found itself in the midst of food importation. Adeniyi et al (2009), Adebayo (2010) and Abdulrahaman (2013), confirmed the existence of food insecurity in Nigeria. What causes the crisis is a subject of debate among scholars. For example Abdulrahaman (2013) is of the opinion that, the amount of statutory allocation given to the sector is too small for the sector to achieved its primary objective. Adeniyi et al (2009) pointed at poor agricultural policies and programs and the ways and procedures on how agricultural loans are disbursed to the farmers respectively are responsible for low agricultural productivity. In his contribution Adebayo (2010) blamed the effects of deregulation policies on agricultural sector as a consequence to food security. Other factors include high increase in the prices of food stuffs and the hand-work of hoarders in sabotaging enough food in the market.

\section{METHODOLOGY}

\section{1. Source of Data}

This study is aimed at examining the interplay of domestic food production and food importation to the overall Gross Domestic Product (GDP) of Nigeria's economy (a proxy measure of the nation's wellbeing) using the time series data between 1960-2012. The data used in the study are the sectoral component shares of the Nigerian GDP, component shares of agriculture to the overall GDP (as a proxy value of domestic food production), and the values of food import (in $\mathrm{N}$ million). Data were obtained from the National Bureau of Statistics and Central Bank of Nigeria Annual report (CBN Statistical Bulletin, 2010); CIA Factbook (2013) and NPC annual report (2012).

\section{2. Data Analysis and Model Specification}

Trend analysis and multiple regression analysis were used to examine the effects of component shares of agricultural production and food imports on the gross domestic product of the nation which serves as a pseudo measure of the nation's ability to meet the food needs of the populace.

\section{3. Double_Log Regression analysis:}

The model is explicitly expressed as:

$$
\operatorname{LnGDP}=\operatorname{Ln} \propto+b_{1} \operatorname{Ln} X_{1}-b_{2} \operatorname{Ln} X_{2}+\operatorname{Ln} \varepsilon
$$


where:

LnGDP $=$ Gross Domestic product (at current basic prices, 1960-2012), Ln $\propto=$ Intercept, $b_{1}-b_{2}=$ regression coefficients, $\operatorname{Ln} X_{1}=\log$ contribution of Agriculture to GDP (in N m), $L n X_{2}=\log$ of annual food import bill (in $\mathrm{N} \mathrm{m}$ ) and $L n \varepsilon=\log$ of white noise error term assumed to be 1 .

\section{RESULTS AND DISCUSSION}

\section{1. Trend Analysis}

Table 1 and Figure 1 show the contribution of agriculture and naira values of food import as the percentage of GDP of Nigeria. The contribution of agriculture depicts a downward trend from 1960 to 1979 (61.65 to $23.80 \%$ ), whereas, the value of food imports were relatively stable at about $2.92 \%$ between 1960-1974.

This observation is consistent with earlier findings by Ahungwa et al (2014) and Anyanwu et al (2013) which showed the dominance of agriculture share of GDP in the first two decades, though at a declining rate. The reason could be attributed to the fact that the nation's only alternative to economic sustenance was agriculture.

Table 1. Values of Agriculture and Food imports in relation to the total GDP of Nigeria (1960-2012).

\begin{tabular}{|c|c|c|c|c|c|}
\hline \multirow{2}{*}{ Year } & Total GDP & \multicolumn{2}{|c|}{ Agriculture } & \multicolumn{2}{c|}{$\begin{array}{c}\text { Value of food import (excluding } \\
\text { vegetable oil and animal fats) }\end{array}$} \\
\cline { 2 - 6 } & N'm & GDP N'm & $\%$ & N'm & $\%$ \\
\hline $1960-1964$ & 2568.40 & 1579.64 & 61.65 & 45.04 & 2.87 \\
\hline $1965-1969$ & 3088.58 & 1640.26 & 53.27 & 42.1 & 2.55 \\
\hline $1970-1974$ & 9314.62 & 3268.40 & 39.69 & 104.58 & 3.13 \\
\hline $1975-1979$ & 31233.22 & 7328.64 & 23.80 & 760.62 & 9.85 \\
\hline $1980-1984$ & 51809.44 & 16426.78 & 31.30 & 1602.04 & 10.62 \\
\hline $1985-1989$ & 119632.20 & 44270.86 & 38.12 & 1575.04 & 3.69 \\
\hline $1990-1994$ & 539207.30 & 181622.32 & 32.55 & 9429.96 & 5.21 \\
\hline $1995-1999$ & 2668070.00 & 920018.08 & 34.32 & 94025.02 & 10.52 \\
\hline $2000-2004$ & 22500196.0 & 2734641.32 & 37.05 & 159706.6 & 6.80 \\
\hline $2005-2009$ & 20560630.0 & 6929310.42 & 33.50 & 264868.0 & 3.83 \\
\hline $2010-2012 *$ & 37129386.5 & 12368898.7 & 37.02 & 2057333.3 & 25.02 \\
\hline
\end{tabular}




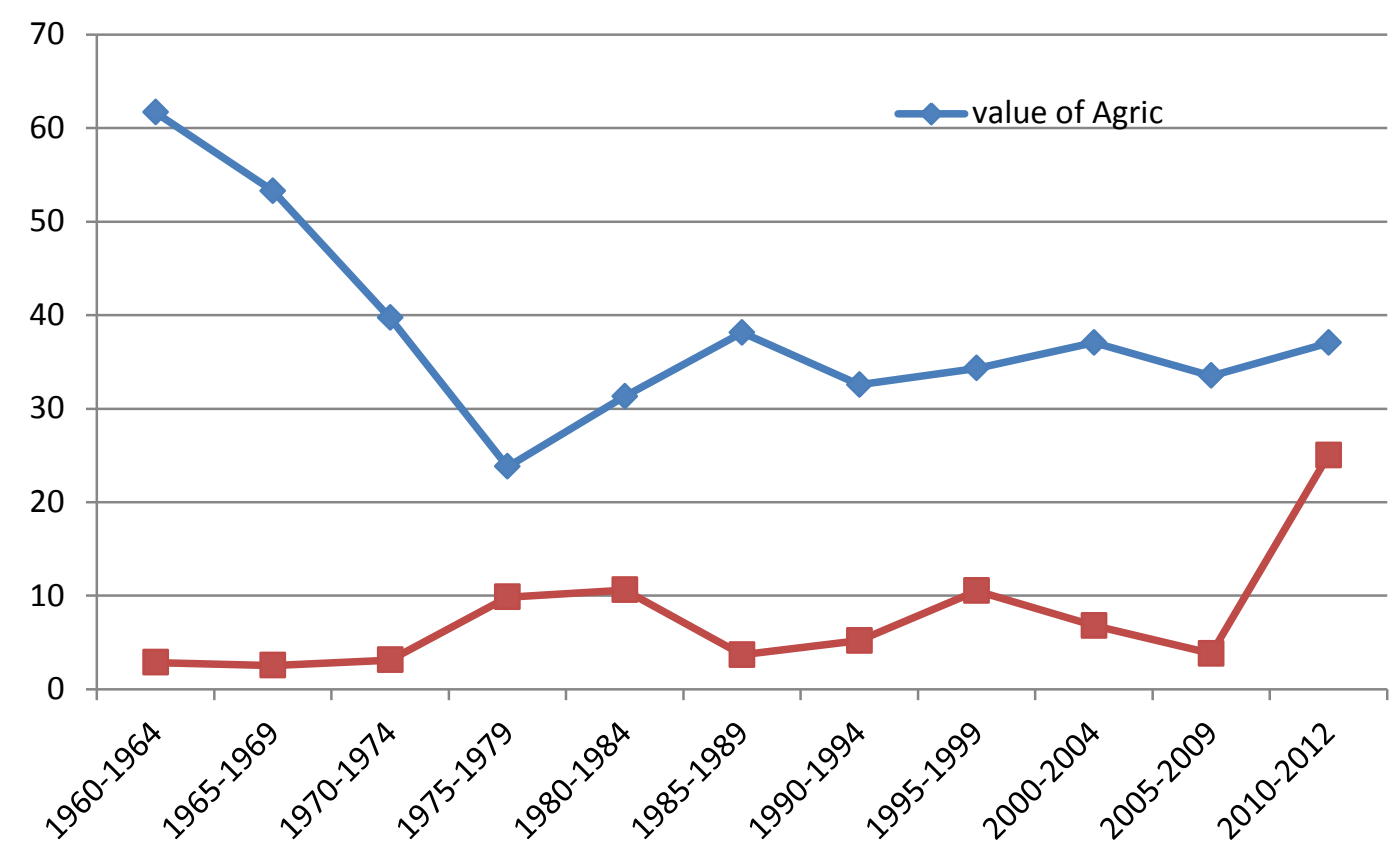

Fig. 1. Values of the contribution of Agriculture to GDP and food import (1960-2012).

Then, agriculture was able to play its traditional roles of food provision, earning of foreign exchange and provision of raw materials to the industries. However, there were drastic changes especially in the amount of food importation resulting from the neglect of the agricultural sector prior to the discovery of oil and also the resultant effect of the civil war in 1967-1970. Agricultural production declined and food importation rose sharply from $9.85 \%$ to $10.62 \%$ in 1975-1979 and 1980-1984, respectively. The sudden increase in food importation could also be linked to the windfall from oil sector and sudden change in taste for foreign food by an average Nigerian. Agricultural sector continued to strive, contributing annually to the nation's GDP at an undulating rate between $31.30 \%$ in $1980-84$ to $37.02 \%$ in 2010-2012. Food importation however, decline from 10.62 \% in 1980-84 to 5.21 \% in 199094. The situation was reverse and food import rose to $10.52 \%$ again between 1995-99. The advent of political dispensation ushered in a new dimension to the agricultural sector with introduction of a number of agricultural programmes and initiatives that generated so much interest among farmers. However, according to FGN Vision 20:2020 (2009) such initiatives lacked concurrent provisions for storage and processing facilities, thus resulting in large postharvest losses and apathy on the side of the farmers.

The situation become alarming within the interval of 2010-2012 wherein agricultural share to GDP was $37.02 \%$ with an amazing figure of food import of $25.02 \%$. Principal reason for such could be attributed to the resultant effect of the 2012 flood that affected over 12 states of the federation. Within this interval, the actual monetary values of food import rose from N4.2 trillion to N24.5 trillion, an amount five times the nation's annual budgets

\section{2. Regression Results}

The Double-Log regression model was used to explain the impact of the shares of agricultural sector and the values of food import on the GDP. The results of the regression shows that there is a positive relationship between the dependent variable (GDP) and the 
share of agriculture which also conform to the a priori expectation that agriculture is positively related to the GDP. The magnitude of the coefficient of agriculture (0.852) is statistically significant at $1 \%$ level. This implies that a percent increase in the share of agriculture will contribute to about $85.2 \%$ change in the GDP of Nigeria. The findings further confirm the pivotal role of agriculture to the Nigeria' economy (Kola, 2011; Umaru and Zubairu, 2012; Anyanwu et al., 2013, and Ahungwa et al,. 2014).

The paradox however, is that the coefficient of food import, expected to be inversely related to the GDP was found to be positive, though not statistically significant. This negates the findings of Muhammad and Atte (2006) which indicated that as food import increases, domestic agricultural production decreases. Nonetheless, statistical figures available showed otherwise. Whereas the domestic food production was on a marginal increase, especially in the recent years, due to government renewed efforts in agriculture, food importation is rather on the increase. Deductively, it could be averred that food imports is contributing rather to the GDP through raised import duties and tariffs (e.g. 100\% on rice), as well as internally generated revenues from such business ventures. Empirically, the negation could to be attributed to the facts that the various government initiatives that generated interest in agricultural production were without concurrent provisions for storage and processing, thus resulting in large postharvest losses and apathy on the side of the farmers (FGN, 2009). Moreso, the population increase that has jumped from 160 million in 2006 to about 170 million in 2012, thus bringing Nigeria to the $7^{\text {th }}$ most populous nation, is not accompanied with corresponding domestic food production. This is in consonance with the view of Nwajiuba, (2012) that domestic food production is unable to feed the growing population.

The $\mathrm{R}^{2}$ of 0.994 implies that 94.4 percent of total variance in GDP is explained by the regression equation. Coincidentally, the goodness of fit of the regression remained same after adjusting for the degrees of freedom as indicated by the adjusted $\mathrm{R}^{2}\left(\mathrm{R}^{2}=0.987\right.$ or $\left.98.7 \%\right)$. F-statistics 1960.46, which is the measure of the joint significance of the explanatory variables, is found to be statistically significant at 5 percent as indicated by the corresponding probability value $(0.000)$.

Table 1. Parameters of Regression Results of Agriculture and Food Import of the GDP against total GDP.

\begin{tabular}{|c|c|c|c|}
\hline Variables & Coefficients & t-statistics & Sig. \\
\hline (Constant) & - & 2.892 & $.006^{* *}$ \\
\hline Agriculture & .852 & 10.548 & $.000^{*}$ \\
\hline Food Import & 0.144 & 1.783 & .081 \\
\hline R-square & 0.994 & \\
\hline Adjusted R-Square & 0.987 & $.000^{*}$ \\
\hline F-statistic & 1960.457 & & \\
\hline * Significant at 1 \%, ** = Significant at 5\%.
\end{tabular}




\section{CONCLUSION AND RECOMMENDATIONS}

The Nigeria food equation hangs on a delicate balance of domestic food production that is heavily dependent on natural forces and volatile food imports that is only sustainable as long as the proceeds from the oil sector keep flowing. The concurrent increase in domestic food production and food import were as a result of monumental postharvest losses resulting from inadequate storage and processing facilities, growing consumer population and overdependence of the agriculture on weather that is highly unpredictable.

The paper recommends that to minimises the increasing reliance on food import, it is essential that productivity enhancing measures be implemented in the agricultural sector such that food production can expand at a rate that is commensurate with food deficit caused by increasing population. This could be achieve through increased budgetary allocation to the agricultural sector, raising of embargo on food produce that the nation has comparative advantages to produce and introduction of postharvest saving mechanism that will minimize wastages that have hitherto, exacerbated food security in the country.

\section{References}

[1] Abdulrahaman S., International Journal of Social Science Tomorrow 2(1) (2013) 1-6.

[2] Adebayo A. A., Int. Journal of Economic Research and Investment 1(1) (2011) 132-150.

[3] Adeniyi I. M., AbdulRasheed A., Bello A. I., Journal of International Economic Review 2(1-2) (2009) 167-176.

[4] Adetiloye K. A., J Economics 3(1) (2012) 39-48.

[5] Agriculture in Nigeria (2011). State of Food Security in Nigeria. Retrieved on 2nd October, 2011 from http://aricultureinnigeria.blogspot.com/2011/04/state-of-food-security-innigeria.

[6] Ahungwa G. T., J. C. Umeh, Muktar B. G., International Organisation of Scientific Research Journal of Agriculture and Veterinary Science 6(1) (2013) 57-62.

[7] Agriculture to the Gross Domestic Product of Nigeria (1960-2012). International Organisation of Scientific Research Journal of Agriculture and Veterinary Science (IOSR-JAVS), 7(1); 50-55.

[8] Akande S. O. (1998). Public policy in Nigeria agriculture In Institutional reforms for Agriculture development. Oludimu O.L. and Imodu P.B. (eds) Triumph Books Publishers, pp. 20-54.

[9] Anyanwu S. O., U. S. Offor, O. M. Adesope, Ibekwe U. C., Global Advanced Research Journal of Management and Business Studies 2(6) (2013) 342-348.

[10] Azubike G. (2012). Nigeria: Food Insecurity as a time bomb, March 2012: (http://allafrica.com/stories/201203110293.html), accessed 25/11/2013.

[11] CBN (2010). Central Bank of Nigeria: Statistical Bulletin, 2010 Edition

[12] Corporate Nigeria (2009). The Business, Trade and Investment Guide 2010/2011, www.corporatenigeria.net, accessed 1/22/2014. 
[13] Ehigiamusoe U. K., International Journal of Humanities and Social Science Intervention 1(1) (2012) 13-23.

[14] Famoriyo O. A., Applied Tropical Agriculture 3(1) (1998) 1-9.

[15] FGN (2009). Report of the Vision 2020 National Technical Working Group on Agriculture and Food Security, July 2009.

[16] Food and Agricultural Organization (2011). Global food losses and waste: Extent, causes and prevention. Study conducted for the International congress (FAO) Rome.

[17] Iganiga B. O., D. O. Unemhilin, Journal of Economics 2(2) (2011) 81-88.

[18] Iwuchukwu J. C., Igbokwe E. M., Journal of Law, Policy and Globalization 5 (2012).

[19] Isife B. I., C. O. Abert, The perception of Extension Professionals Agric. Journal 4 (2009) 22-26.

[20] Kola D., Publication of Central Bank of Nigeria 25(3) (2001) 32-38.

[21] Lawal A. A. (1997). The economy and the state from the pre-colonial times to the present. In Osuntokun, A and Olukoya A (eds). Nigeria People and culture Ibadan; Davidson.

[22] Muhammad L. A., O. A Atte, African Journal of General Agriculture 2(1) (2006) 132-150.

[23] Nwajiuba C. (2012). "Nigeria's Food Security Challenges", www.nestinterative.org, accessed, 11/25/2013.

[24] Ogen O. (2003). Patterns of Economic growth and development in Nigeria since 1960. In Arifalo S.O. and Ajayii (eds) (2003). Essays in Nigerian contemporary History. Lagos: first academic publishers

[25] Okunneye P. A., CBN Economic and Financial Review 39(4) (2002) 6.

[26] Olayide S. O. (1982). Food and Nutrition Crisis in Nigeria. Ibadan: Card.

[27] Osagie C. (2013). Year 2013: The Struggle to Stem Indiscriminate Food Importation, Thisday Newspaper, 31 Dec. 2013. www.thisdaylive.com/news accessed, 6/3/2014.

[28] Tollens F. (2000). Food Security: Incidence and Causes of Food Insecurity Among Vulnerable Groups and Coping Strategies, In, CTA (2000) Food Insecurity in ACP Countries, Proceedings of a CTA Seminar, pp. 27-50.

[29] Umaru A., A. A. Zubairu, International Journal of Social Science and Education 2(4) (2012) 12. 